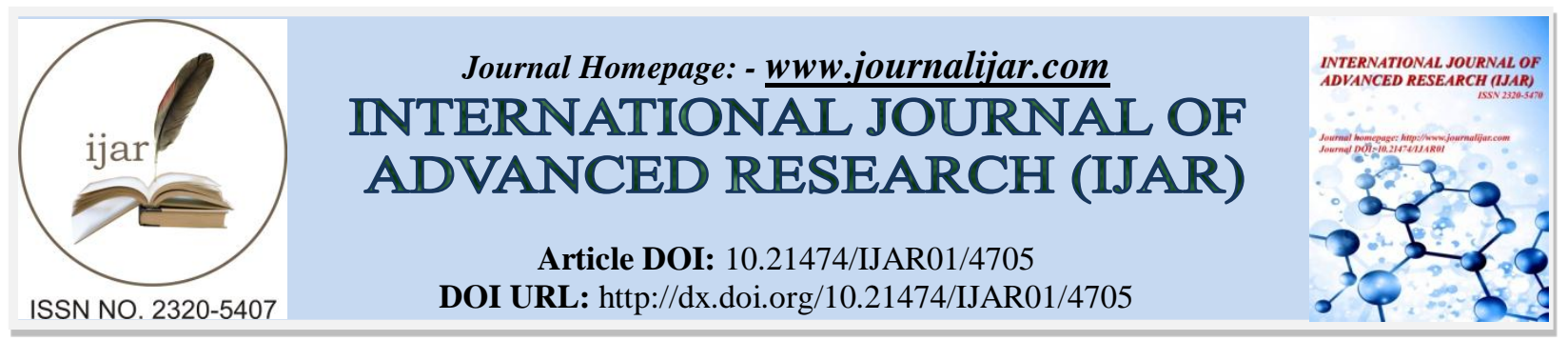

RESEARCH ARTICLE

\title{
RECONSTRUCTION OF SANCTIONS ON MEDICAL PROFESSION THAT HARM PATIENTS BASED ON JUSTICE VALUE.
}

Edi Sumarwanto.

Student of the Doctoral Law Program, Sultan Agung Islamic University Semarang, Jalan Raya Kaligawe Km 4 Semarang Indonesia 50112

\section{Manuscript Info}

........................

\section{Manuscript History}

Received: 2 May 2017

Final Accepted: 4 June 2017

Published: July 2017

Key words:-

medical profession, sanction, Pancasila.

\section{Abstract}

If a patient feels aggrieved by the practice of medicine can make a complaint to the Indonesian Medical Disciplinary Board. Complaints to the Indonesian Medical Disciplinary Board do not diminish the patient's right to report the physician for alleged criminal acts to the authorities and or to sue for civil injury to the court. Giving sanctions to the medical profession is not considered to meet the value of justice. Reconstruction of several Articles in Law number 29 of 2004 on Medical Practice is indispensable, among others: Article 3 a Medical Practice Law and Article 66 paragraph (3) of Medical Practice Law and Article 69 paragraph (3) of Medical Practice Law. In article 66 paragraph (3) explains that any violation of the medical profession must first be terminated through Indonesian Medical Disciplinary Board institution. The process of complaint is the author called "One Door Court." In order for the theory of one-door justice can run effectively then required Indonesian Medical Disciplinary Board provincial and district throughout Indonesia. Reconstruction type of sanction (Article 69 paragraph (3)) intended for the implementation of sanctioning the medical profession always mengedapankan prophetic justice that is justice based on Belief in God Almighty.

\section{Introduction:-}

Doctors are medical health workers who provide services according to the competencies gained during education, according to service standards (medical, procedures, professional behavior). Doctors in running the profession, bound by various norms and can be given sanctions if it violates. ${ }^{1}$ The three areas of norm or rule are the guidelines and benchmarks of a doctor or dentist to determine whether a doctor or dentist's behavior is guilty or not in practice. The three norms are: ethical norms, norms of professional discipline, and legal norms. In addition, every doctor or dentist is bound by norms or rules as individuals, as citizens and as members of the medical profession and profession who practice medicine.

1 Fitri, Profesi Dokter: Definisi, Kompetensi Dasar dan Tugas Dokter, http://sehat.link/definisi-dansejarah-terbentuknya-profesi-dokter.info, posted on October 30, 2014, accessed on September 16, 2015 , at 10:27 $\mathrm{pm}$. 
Good medical practice is a practice based on standard medical operational procedures, medical service standards, does not deviate from the area of competence, professional conduct, maintain medical ethics and always make informed consent in the act, keep the patient confidential, following the provisions of legality/legislation applicable. Surely the practice of a doctor aims to heal the patient, because the profession of the doctor is a profession of noble and noble, can help patients suffering. The cornerstone of medical services is the understanding of the need for proper medical action, based on medical science and technology and the competence of skill development and understanding of the demands of society. The principle of medical services always refers to the Standard Medical Service as well as efforts to maintain the quality of service. The implementation of good medical practice has been regulated in Chapter VI of Indonesian Medical Council Decision number 18/KKI/KEP/IX/ 2006.

In performing the duties of his profession, a doctor or dentist may commit a violation, both a violation of ethical norms, norms of discipline and legal norms. The Indonesian Doctors Association has the duty to uphold the existing ethical norms of medicine, the Indonesian Medical Disciplinary Board based on the medical practice law has the duty to uphold the discipline of doctors and dentists in the conduct of medical practice, established the Indonesian Medical Disciplinary Board. The Indonesian Medical Disciplinary Board is an autonomous institution of the Indonesian Medical Council. The Indonesian Medical Disciplinary Board in carrying out its duties is independent (Article 55 of Law No. 29 of 2004 on Medical Practice). While the legal norms enforced by the police/court.

If a patient feels aggrieved by the practice of medicine can make a complaint to the Indonesian Medical Disciplinary Board against a doctor/dentist. Complaints to the Indonesian Medical Disciplinary Board do not diminish the patient's right to report the physician for alleged criminal acts to the authorities and or to sue for civil injury to the court. This is as regulated in Article 66 of Law Number 29 of 2004 concerning Medical Practice.

From the provisions in Article 66 it can be concluded that a doctor and dentist who commits a disciplinary offense can be complained to the Indonesian Medical Disciplinary Board. Complaints to the Indonesian Medical Disciplinary Board do not deprive everyone of the right to file their losses to the court (legal domain). This results in a doctor or dentist can get double sanctions. Based on the above matters, the authors are interested to reconstruct the provision of sanctions on the medical profession that harms the interests of patients based on the value of justice.

\section{Discussion:-}

\section{Patient's Interests:-}

Patients include consumers of health services. In the General Explanation of Consumer Protection Law stated that the Consumer Protection Act is basically not the beginning and end of the law that regulates the protection of consumers, because until the formation of Consumer Protection Act there have been several laws that the material protect consumers, such as Act number 23 of 1992 on Health which has been changed into Law of the Republic of Indonesia number 36 of 2009 on Health. ${ }^{2}$ Thus Consumer Protection Law becomes the umbrella act for other laws related to the consumer. Similarly, respect for the rights, both the rights of patients in particular, and the rights of consumers in general. In performing their duties every health worker is also bound and subject to legal and ethical norms. Violations of the law and ethics have consequences for the imposition of sanctions to be carried out.

Doctors and patients are two legal subjects related to each other in medical law. Both form a medical relationship and legal relationship. The medical connection and the legal relationship between physician and patient is the relationship to which the object of health services. In carrying out the relationship between physician and patient, the implementation of the relationship between the two is always regulated with certain rules for harmony in the implementation. In the context of physician and patient relationship, both doctors and patients have their respective roles. These roles can be analyzed in terms of the four basic dimensions of universal, limited, permanent-temporary, non-voluntary and subordinate-non-voluntary. ${ }^{3}$

Limited-universal means that the number of doctors in this case the physician in the community is limited, while the patient is universal, uncertain, everyone can fall ill and act as a patient. Permanent-temporer, where the profession as

2 Elyani, Perlindungan Hukum Bagi Konsumen Kesehatan Dalam Hal Terjadi Malpraktik, https://jmmymartin. wordpress.com/2012/06/03/perlindungan-hukum-bagi-konsumen-kesehatandalam-hal-terjadi-malpraktik/, posted on June 3, 2012, accessed on February 10, 2016, 9pm..

3 George M. Foster, Barbara Gallatin Anderson, Penterjemah: Priyanti Pakan Suryadarma, Meutia F.

Hatta Swasono, 2006, Antropologi Kesehatan, Jakarta: Penerbit Universitas Indonesia, p. 123 
a doctor is generally done someone continuously and permanently, while as a patient, someone will not be patient. Superiors, generally the connotation of a superior is someone who has the right to govern his subordinates. In this connection, the physician because of his scholarship often requires his patients to obey what he wants with the aim that his patients recover quickly. In the case of voluntary non-volunteers, a person who works as a doctor generally volunteers, and as a patient is generally forced, because of illness.

\section{Code of Ethics of Medicine, Medical Discipline and Norms of Medical Law:- Code of Ethics of Medicine:-}

Ethics is a part of philosophy that includes living well, being a good person, doing good and wanting good things in life. ${ }^{4}$ Ethics, like the method of philosophy, contains exploratory and explicit arguments to justify certain actions (practical ethics). Also discusses the principles that govern the ideal human character or code of ethics of a particular profession (normative ethics). ${ }^{5}$ Ethics is a guide to do things for a reason. So ethics is also the reason for choosing the correct value amid the wilds of the norm (moral philosophy). ${ }^{6}$

Ethics requires doctors to be absolutely, but not at all pushy. So doctors remain free. Can obey or ignorant. When violating: kamil man (moral conscience=conscience) it will reprimand so arise guilt, regret, not calm. Nature of medical ethics:

1. Special ethics (not entirely equal to common ethics).

2. Social ethics (obligation to other human / patient).

3. Individual ethics (liability to self=selfimposed, zelfoplegging).

4. Normative ethics (referring to the deontology, the obligation toward norms that are often fundamental and contain 4 sides of obligations=gesinnung ie self, public, peers and patients/clients and other special community).

5. Professional ethics (usual):

a. The social ethics section of professional obligations and responsibilities;

b. A special ethical section that questions values, norms/obligations and moral virtues.

c. Some of its contents are protected by law, such as the right to freedom to keep the secret of the patient/secret of office (verschoningsrecht).

d. Can only be formulated based on the knowledge and experience of the medical profession.

e. To answer the problems at hand (not a priori ethics); For centuries, the good and the bad are put into the code of conduct (as a collection of norms or morality professions).

Such rapid developments in biology and medicine make medical ethics incapable of accommodating all the problems related to life. Medical ethics talks about the medical field and the medical profession only, especially the physician's relationships with patients, families, communities, and peers, therefore since the last three decades have been developed bioethics or called biomedical ethics. ${ }^{7}$

Medical biophysics is one of the special ethics and social ethics in medicine that fulfills the praxeological (practical) and moral (normative) norms that serve as a guideline (das Sollen) as well as a reflective critical attitude (das Sein), derived from the four basic moral rules and their derivative rules. Basic moral rules along with ethical theories and ethical systematics containing basic ethical values are the cornerstones of the ethics of the noble profession of medicine. The ethical responsibility which is the conscience of a physician will retain the ethical behavior of all members of the profession in order that the future physician corps remains a noble profession with each member each having the sanctity of conscience. ${ }^{8}$

4 Robert C. Solomon, 1984, Etika, Suatu Pengantar, Jakarta: Erlangga, p. 2

5 Webster's New Dictionary of Synonyms. Springfield, MA : Merriam-Webster, 1984, p. 547

6 Compare the ethical limits (Ki Hajar Dewantoro, 1962): "the study of all things of good (and evil) in human life, all of which, especially about the movements of mind and taste which can be considerations and feelings, To the point that it can be an act".

7 M. Jusuf Hanafiah dan Amri Amir, 2007, Etika Kedokteran dan Hukum Kesehatan, Edisi 4, Jakarta: Penerbit Bukum Kedokteran EGC, p. 3

8 Agus Purwadianto, Kaidah Dasar Moral Dan Teori Etika Dalam Membingkai Tanggungjawab Profesi Kedokteran, https://mymodul.wordpress.com/2011/01/18/kaidah-dasar-moral-dan-teorietika-dalam-membingkai-tanggungjawab-profesi-kedokteran/posted on January $18, \quad 2011$ by fitrianingrum admin, Accessed on September 17, 2015, at 08.48. 


\section{Medical Discipline:-}

Medical discipline is the rules and/or provisions of the application of science in the implementation of services to be followed by doctors and dentists (Article 1 number 1 Indonesian Medical Council Regulation number 4 of 2011 on Professional Discipline of Doctor and Dentist). In Article 3 paragraph (2) is also set in detail discrimination professional discipline doctor and dentist consisting of 28 forms, are as follows:

1. performing medical practices incompetently;

2. does not refer the patient to another doctor or dentist who has the appropriate competence;

3. delegate work to certain health personnel who are not competent to carry out the work;

4. providing a surrogate physician or dentist who has no appropriate competence and authority or does not make notification of such replacement;

5. performing medical practice under conditions of physical or mental health in such a manner as to be incompetent and harmful to the patient;

6. does not take adequate medical care/action in certain situations that may endanger the patient;

7. conduct excessive examination or treatment that is not in accordance with the needs of the patient;

8. does not provide an honest, ethical, and adequate (adequate information) explanation to the patient or his family in conducting medical practice;

9. performing medical acts without obtaining the consent of the patient or immediate family, guardian or his/her counterpart;

10. does not make or keep a medical record intentionally;

11. commits an act aimed at stopping a pregnancy that is not in accordance with the provisions of applicable laws and regulations;

12. commit acts that may terminate the life of the patient at his or her own request or family;

13. undertake medical practice by applying knowledge, skills or technology not yet received or outside the appropriate medical practice procedures;

14. conducts research in medical practice using humans as a subject of research without obtaining ethical clearance from a government-recognized institution;

15. does not conduct emergency assistance on the basis of humanity, whereas it does not endanger him unless he is sure there are others who are on duty and able to do so;

16. deny or terminate any medical treatment or treatment of a patient for no reason which is reasonable and valid in accordance with the provisions of professional ethics or applicable laws and regulations;

17. unlock the secrets of medicine;

18. make medical information not based on the results of the examination that it knows correctly and appropriately;

19. participates in acts which include torture or execution of the death penalty;

20. prescribe or administers drugs of narcotic, psychotropic, and other addictive substances that are not in accordance with the provisions of professional ethics or applicable laws and regulations;

21. sexually harasses, intimidates, or acts of violence against patients in the conduct of medical practice;

22. using an academic degree or a profession designation not entitled;

23. receive compensation as a result of referring, requesting an examination, or prescribing a health fly medication;

24. advertise the capability/service or overload of services possessed either oral or written incorrect or misleading;

25. addiction to narcotics, psychotropic, alcohol, and other addictive substances;

26. practicing by using the registration certificate, license of practice, and/or certificate of competence that is not valid or practicing without having a license of practice in accordance with the provisions of applicable laws and regulations;

27. is dishonest in determining medical services;

28. does not provide information, documents and other evidence required by the Indonesian Medical Disciplinary Board for examination of alleged infringement of professional discipline of doctor and dentist;

To enforce the discipline of doctors and dentists in consumer protection legislation established the Indonesian Medical Disciplinary Board. This is the institution that will be authorized to determine whether there is a mistake by doctors and dentists in the application of medical and dental disciplines. The Indonesian Medical Disciplinary Board is an autonomous institution of Indonesian medical council which is independent and domiciled in the Capital City. Only when required by Indonesian Medical Council's proposal can also be established at the provincial level. ${ }^{9}$ The existence of the Indonesian Medical Disciplinary Board is instrumental in upholding the discipline of the medical

9 M. Jusuf Hanafiah dan Amri Amir, op.cit., p. 39 
profession or dentistry, so it is important to be known by the parties related to the profession either doctors/dentists and students of medicine/dentistry.

\section{Norm Law Health / Medical Law:-}

According to expert lawyer Van Der Mijn, the definition of health law is defined as a law that is directly related to health care which includes the application of civil law, criminal and state administrative law or the definition of health law is as a whole juridical activities and legal regulations in the field of health and As well as his scientific studies. According to Leenen Health, health as a whole of juridical activity and legal regulation in the field of health and scientific studies. In Article Article 1 point (1) Act number 23 of 1992 on health, the health stated that the socalled healthy is a prosperous state of body, soul, and social that allows every person to live productively socially and economically.

In the Articles of Indonesian Health Law Association stated that health law is all legal provisions that are directly related to maintenance/health service and its application. This concerns the rights and obligations of both individuals and all levels of society as recipients of health services as well as health providers in all its aspects, organizations, facilities, standards of medical service, health and law science and other legal sources. Medical law is a part of health law, that is concerning medical care/service (medical care/sevice).

The subject of the $\operatorname{law}^{10}$ is anything that can have the right and obligation to act in law. Consists of persons and legal entities. Meanwhile the subject of health law is patient and health personnel including health institution while the object of health law is health care (Zorg voor de gezondheid). If the object of health law is health care then the object of medical law is medical service; so it can be said that medical law is a health law in the narrow sense.

\section{In the law of health also known principles of health law, among others:-}

1) The principle of humanity based on the belief in the one and only God;

2) The principle of benefit;

3) The principle of joint effort and kinship;

4) Fair and equitable principle means;

5) The principle of life in equilibrium;

6) The principle of trust in the ability and strength itself.

Health law resources are not only from written law but also from jurisprudence, treaties, conventions, doctrines, consensus and opinions of lawyers and medicine. The sources of health law are; legislation that directly or indirectly regulates health issues, including international regulations. The principle of the applicable principles of inter-state in international relations, good habits and followed continuously in the field of health, jurisprudence or judicial decisions that have had permanent legal force in the field of health/medicine and scientific doctrine. ${ }^{11}$

10 The subject of the law:

a. Subject of Human Law

It is everyone who has the same position as the supporter of rights and duties. In principle people as the subject of the law from birth to death.

There are also groups of people who can not be subject to the law, because they are not proficient in performing legal acts, namely:

1. Children who are underage, immature, and unmarried.

2. People who are in the forgiveness of people who are sick memories, drunks, spenders.

b. Subject of Corporate Law:

Is a sustu association or institution made by law and have a specific purpose. As a legal subject, business entities have the conditions prescribed by law, namely:

1. Having wealth separated from the wealth of its members.

2. Rights and Duties of a legal entity separate from the rights and obligations of its members.
Asep
Oustom,
Batasan
Ruang
Lingkup
Hukum Kesehatan,

https://chevichenko.wordpress.com/2009/11/28/ batasan-ruang-lingkup-hukum-kesehatan/, posted on November 28, 2009, accessed on October 26, 2015, at 10.43. 


\section{Reconstruction of Sanctions on Medical Professions Adversely Affects the Importance of Justice-Based Patients:-}

F. Tengker argues that community traffic is not only governed by the rule of law, but also by a variety of rules, which can be covered by the designations of the rules are in essence stimulated by sanctions, both negative and positive over the behavior The distorted or the following. ${ }^{12}$ The existence of sanctions is intended for the enforcement of the law to proceed as it should. If the law runs well it will create legal protection, both preventive and repressive law protection.

A medical action to be performed by a physician should also prioritize the principle of benefience, where the principle always puts the action intended for the good of the patient. The work done must have a greater benefit than the loss. This is reinforced by the principle of non-maleficence which prohibits all actions that can aggravate the state of the patient and the principle of justice that emphasizes fairness and fairness in attitude.

From the time of Socrates to Francois Geny the theories of natural law retain justice as the crown of law where the natural law theory prioritizes "the search for justice". ${ }^{13}$ Gustav Radbruch ${ }^{14}$ disclose three basic values that want to be pursued and must get serious attention from the executor of the law that is the value of justice, legal certainty, and expediency.

If there is a conflict between the principles of justice, benefit and legal certainty, according to Sudikno Mertokusumo, then the principle of justice, where justice takes precedence from legal certainty to make the challenge for the law to always develop and catch up with changes in society, while the principle of justice is preferred The principle of expediency is because in many ways politically the benefits are more accessible to the elite and not the community at large. ${ }^{15}$

Law of the Republic of Indonesia Number 29 of 2004 on Medical Practice is made by the legislator to protect the medical profession in carrying out his professional duties. In addition, the Medical Practice Act is tailor-made to ensure that doctors feel safe in working so that patients are protected. The author argues that there are several articles in the medical practice law that need to be reconstructed so as not to further agitate the medical and dental professions. Based on the above description, reconstruction of the value of medical sanctions that harm the interests of patients is to provide balanced legal protection between patients, doctors/dentists and hospitals based on prophetic justice.

This Islamic paradigm was developed by Kuntowijoyo, a professor of history at the Faculty of Cultural Sciences, Gadjah Mada University Yogyakarta in about $2000 .{ }^{16}$ This concept is further clarified by Heddy Shri Ahimsa-Putra who gave birth to the concept of the prophetic paradigm.

The prophetic science of Kuntowijoyo's prophetic ideas is inspired by two great thinkers namely Muhammad Iqbal (an Islamic thinker) and Roger Garaudy (a French thinker who later converted to Islam). For the science of law, the emergence of this prophetic thinking feels the soul and a new container that should be developed as a local genius legal education. ${ }^{17}$

Justice is one of the goals of any legal system even its most important purpose. Greek philosophers view justice as an individual virtue. Therefore within the Institute of Justiniam provides a very well-known definition of justice, which defines justice as a continuous and constant goal to give everyone their due.

12 F. Tengker, 1993, Hukum Suatu Pendekatan Elementer, Bandung: Nova, p. 20-21

13 Theo Hujibers, 1995, Filsafat Hukum dalam Lintasan Sejarah, Yogyakarta: Kanisius, p. 196

${ }^{14}$ Gustav Radbruch, 1996, Einfuhrung in die Rechtswissensschaft, Stuttgart: K.F. Koehler, 1961 dalam Satjipto Rahardjo, Ilmu Hukum, Bandung: Citra Aditya Bakti, p. 19-21

${ }^{15}$ Aryanto Kush Anjawani, Memorandum untuk Komisi Yudisial, http://lenterahukum.com/?p=24, was downloaded on September 28, 2011. This is in accordance with Article 12 of the Draft Concept of the Criminal Code 2005-2006 and the last Draft Draft of the Criminal Code of 2012 that in applying the decision as far as possible to apply justice above certainty.

${ }^{16}$ Gagasan ini bersamaan dengan munculnya wacana Hukum Progresif yang dibidani oleh Satjipto Rahardjo di Fakultas Hukum Undip Semarang sekitar tahun 2001.

17 M. Syamsudin, 2013, Ilmu Hukum Profetik, Yogyakarta: FH UII Press, p. 7 
Profetik Intelligence is an offer of alternative approach in order to participate in filling rule breaking in polemic of law enforcement. PI needed law enforcement to hone his spiritual and spiritual sensitivity. Are not law enforcers also prosecuted in their profession to embody doctrine in every final decision of the law enforcement process, which reads "For Justice by the One Godhead". This doctrine actually requires law enforcers to develop and equip themselves with Profession Intelligence. ${ }^{18}$

The essence of justice that the law enforcers want to decide is the trasendental justice that is really the spirit and the soul is ideal. This concept of justice is meant by prophetic justice. Justice which is full of the divine meanings and values that inspire in a verdict. Prophetic justice is decided not only accounted horizontally to fellow human beings, but also be accounted vertically to Allah SWT, as the Supreme Judge on the Day of Judgment.

In the provisions of Article Medical Practice Act there are some provisions that must be done this judicial reciew to provide legal certainty to the profession of medicine and dentistry in providing health services to the whole community. Some articles that need to be reconstructed include:

\section{Article 3 a Law Number 29 of 2004 on Medical Practice:-}

The provisions of this article provide that the regulation of medical practice has the purpose of providing protection to the patient. Should the protection not only be given to the patient, but protection should also be given to the doctor and/or dentist.

For this reason the provision of Article 3 letter a which reads: "the regulation of medical practice aims to provide protection to patients", which seems to be limited to providing protection to patients should be changed. The amendment of Article 3 letter a is based on progressive legal theory and the theory of preventive legal protection.

Reconstruction of Article 3 letter a as follows: The regulation of medical practice aims to:-

a. Provide protection to patients, doctors or dentists and hospitals;

b. Maintain and improve the quality of medical services provided by doctors and dentists; and

c. Provide legal certainty to the public, doctors and dentists.

\section{Article 66 paragraph (3) of Law Number 29 of 2004 on Medical Practice:-}

The case of doctor Ayu Sasiary for example, in the first court, the Manado District Court frees physician Ayu and friends. Although the Supreme Court has granted the appeal of the Public Prosecutor and sentenced the defendant to imprisonment for ten months respectively, but at the Review of the Supreme Court in Decision Number 79PK/PID/2013 dated February 7, 2014 stated that the defendant was not legally proven to have committed a crime and acquitted the defendant from all charges.

Based on the case it is clear that between the norms of discipline and legal norms have a different scope. So that the violation of disciplinary norms is not necessarily included in a crime. Therefore, if disciplinary norms are brought to justice and proven, then the elements of the crime will not be found. This would be detrimental to the doctor's and society's professions since the judicial process takes a lot of time. Therefore, the provisions of Article 66 paragraph (3) of Law Number 29 of 2004 needs to be reconstructed with repressive protection theory and theory of legislation.

The reconstruction of Article 66 paragraph (3) is as follows:

(1) Anyone who knows or interests are harmed on the actions of a doctor or dentist in carrying out medical practice may complain in writing to the Chairman of the Honorary Board of Indonesian Medical Discipline.

(2) Complaint must at least contain:

a. Identity of complainant;

b. The name and address of the doctor or dentist's office and the time of action; and

c. The reason for the complaint.

(3) In the case of the Indonesian Medical Disciplinary Board, if the complaint referred to in paragraphs (1) and (2) contains elements of criminal offense/civil loss, the aggrieved party may report to the police and/or take the civil liability to court.

18 Ibid., p. 261 
Reconstruction of the article is intended to create legal certainty about the implementation of sanctioning the medical profession as well as a sense of justice. The sentence of reconstruction of article 66 paragraph (3) is "on the proposal of the Indonesian Medical Disciplinary Board" meaning that any violation of the medical profession in the context of the relationship between the doctor and the patient who complained to the police must be submitted to the Indonesian Medical Disciplinary Board. The Indonesian Medical Disciplinary Board in this case as the only institution authorized to receive, examine and decide upon medical disputes between doctors/dentists with patients.

In this article explains that any violation of the medical profession must first be terminated through the Indonesian Medical Disciplinary Board. This process of complaints the author calls "one door system". The purpose of this theory is that the Indonesian Medical Disciplinary Board is the only institution authorized to decide upon any offense committed by a doctor/dentist in relation to the patient. The existence of one-door court theory is expected to be no more double sanctions for the medical profession but rather more alternative sanctions.

One of the things to note, regarding the theory of one-door justice above is the existence of the Indonesian Medical Disciplinary Board is very positive impact on the process of legal protection both to the doctor and his patients. The need for the existence of the Indonesian Medical Disciplinary Board provincial can not be ruled out anymore. In addition to establishing the Indonesian Medical Disciplinary Board at the provincial level, the socialization related to the existence of the Indonesian Medical Disciplinary Board and its authority must also receive special attention.

\section{Article 69 paragraph (3) of Law Number 29 of 2004 on Medical Practice:-}

Next is the type or form of sanction formulated in Article 69 paragraph (3) must be changed and reconstructed with the theory of justice as contained in Pancasila. When talking about culture, values, ethics and law on the scale of Indonesia should be fundamental to Pancasila, which is a staatfundametalnorm and spirit for the people of Indonesia. Therefore, the realization of justice should be as a mirror in the principles of Pancasila, so that its application must be deity, humane, united, social and social justice. How to create social justice is to create justice based on the belief in the one and only God.

Justice is not limited to its normative nature but the theological justice, which comes from belief in the one and only God or called prophetic justice. Reconstruction of the form or type of sanction in Article 69 paragraph (3) should pay attention to the values of the Deity existing in prophetic justice. The following is the reconstruction of Article 69 paragraph (3) based on the theory of justice (prophetic):

(1) The decision of the Indonesian Medical Disciplinary Board binds doctors, dentists, and the Indonesian Medical Council.

(2) The decision referred to in paragraph (1) may be declared not guilty or disciplinary sanction.

(3) Disciplinary sanctions as referred to in paragraph (2) may be:
a. Written warning
b. Create scientific papers
c. Re-therapy
d. Assigned in another area
e. Teaching at educational institutions
f. Following re-education
g. Conducting social activities
h. Do scientific research
i. Became another physician's assistant
j. Conducting health promotion to the community
k. Do an internship
1. Limitations of doctor's clinical authority

\section{Conclusion:-}

Doctors and patients are two legal subjects related to each other in medical law. Both form a medical relationship and legal relationship. The medical connection and the legal relationship between physician and patient is the relationship to which the object of health services. In performing the duties of his profession, a doctor or dentist may commit a violation, both a violation of ethical norms, norms of discipline and legal norms.

Law No. 29 of 2004 on Medical Practice is made by the legislator to protect the medical profession in carrying out his professional duties. However, the authors argue that there are several articles in the medical practice law that 
need to be reconstructed so as not to further agitate the medical and dental professions. Value reconstruction is aimed at providing balanced legal protection between patients, doctors/dentists and hospitals based on prophetic justice.

Within the provisions of Article Law No. 29 of 2004 on Medical Practice there are some provisions that must be done this judicial reciew to provide legal certainty to the profession of medicine and dentistry in providing health services to the whole community. Some articles that need to be reconstructed include:

1. Article 3 a.

2. Article 66 paragraph (3).

3. Article 69 Paragraph (3).

\section{References:-}

1. Agus Purwadianto, Kaidah Dasar Moral Dan Teori Etika Dalam Membingkai Tanggungjawab Profesi Kedokteran, https://mymodul.wordpress.com/ 2011/01/18/kaidah-dasar-moral-dan-teori-etikadalam-membingkai-tanggungjawab-profesi-kedokteran/

2. Aryanto Kush Anjawani, Memorandum untuk Komisi Yudisial, http://lenterahukum.com/?p=24

3. Asep Oustom, Batasan Ruang Hingkup Hukum https://chevichenko.wordpress.com/2009/11/28/batasan-ruang-lingkup-hukum-kesehatan/

4. Elyani, Perlindungan Hukum Bagi Konsumen Kesehatan Dalam Hal Terjadi Malpraktik, https://jmmymartin.wordpress.com/2012/06/03/perlindungan-hukum-bagi-konsumen-kesehatan-dalam-halterjadi-malpraktik/

5. Fitri, Profesi Dokter: Definisi, Kompetensi Dasar dan Tugas Dokter, http://sehat.link/definisi-dan-sejarahterbentuknya-profesi-dokter.info

6. F. Tengker, 1993, Hukum Suatu Pendekatan Elementer, Bandung: Nova.

7. George M. Foster, Barbara Gallatin Anderson, Penterjemah: Priyanti Pakan Suryadarma, Meutia F. Hatta Swasono, 2006, Antropologi Kesehatan, Jakarta: Penerbit Universitas Indonesia.

8. Gustav Radbruch, 1996, Einfuhrung in die Rechtswissensschaft, Stuttgart: K.F. Koehler, 1961 dalam Satjipto Rahardjo, Ilmu Hukum, Bandung: Citra Aditya Bakti.

9. M. Jusuf Hanafiah dan Amri Amir, 2007, Etika Kedokteran dan Hukum Kesehatan, Edisi 4, Jakarta: Penerbit Bukum Kedokteran EGC.

10. M. Syamsudin, 2013, Ilmu Hukum Profetik, Yogyakarta: FH UII Press.

11. Robert C. Solomon, 1984, Etika, Suatu Pengantar, Jakarta: Erlangga.

12. Theo Hujibers, 1995, Filsafat Hukum dalam Lintasan Sejarah, Yogyakarta: Kanisius.

13. Webster's New Dictionary of Synonyms. Springfield, MA : Merriam-Webster, 1984. 